\title{
PENGEMBANGAN BUDIDAYA IKAN HIAS KOI (Cyprinus carpio) LOKAL DI BALAI PENELITIAN DAN PENGEMBANGAN BUDIDAYA IKAN HIAS DEPOK
}

\author{
Eni Kusrini, Sawung Cindelaras, dan Anjang Bangun Prasetio \\ Balai Penelitian dan Pengembangan Budidaya Ikan Hias \\ Jl. Perikanan No. 13, Pancoran Mas, Depok 16436 \\ E-mail: ennyperikanan@yahoo.com
}

\begin{abstract}
ABSTRAK
Salah satu komoditas ikan hias air tawar introduksi yang sampai saat ini masih menjadi primadona di pasar internasional dan merupakan ikan hias kelompok mahal, serta fluktuasi di pasaranpun relatif stabil adalah ikan koi (Cyprinus carpio). Komoditas ikan hias koi telah menjadi komoditas andalan di beberapa daerah seperti Sukabumi, Cianjur, dan Blitar karena telah berhasil mengangkat perekonomi masyarakat dan menjadikannya sebagai alternatif penghasilan selain padi. Guna mendukung produksi ikan hias koi di beberapa sentra yang ada, dilakukan penelitian untuk mengembangkan budidaya secara intensif yang dilakukan pada lingkungan terkontrol melalui perbaikan teknologi budidaya. Penelitian dilakukan skala lapang di BPPBIH dengan metode survai ke sentra produksi untuk koleksi induk, pembenihan, dan pembesaran dengan menggunakan kolam tanah serta kolam beton untuk pemijahan dan inkubasi telur. Hasil dari penelitian ini berupa data dan informasi teknik budidaya dan produksinya yang dapat digunakan sebagai bahan rekomendasi budidaya ikan hias koi.
\end{abstract}

KATA KUNCI: Cyprinus carpio, budidaya, produksi benih

ABSTRACT: Development of local koi (Cyprinus carpio) aquaculture at Institute of Research and Development Ornamental Fish Culture. By: Eni Kusrini, Sawung Cindelaras, and Anjang Bangun Prasetio

Koi (Cyprinus carpio) is one of commodity freshwater fish introductions that primadona in the international market, high price ornamental fish, and relatively stable market. Koi fish has become valuable commodity in some areas such as Sukabumi, Cianjur, and Blitar because it contribute to economic society and also become alternative revenue in addition to rice. To support koi fish production in some existing aquaculture centers, research to develop intensive cultivation is done in a controlled environment and with improvement of cultivation technology. Research conducted at the field scale RDOFC with the implementation of the research was a survey method of production centers for the collection of system, seed, and magnification using concrete ground pools and ponds for spawning and incubation of eggs.

KEYWORDS: Cyprinus carpio, aquaculture, seed product

\section{PENDAHULUAN}

Salah satu keanekaragaman hayati yang dimiliki Indonesia dan patut dibanggakan adalah keragaman spesies ikan hias air tawar. Ikan hias air tawar diperkirakan sekitar 400 spesies dari 1.100 spesies ikan hias yang ada di seluruh dunia. Salah satu komoditas ikan hias air tawar introduksi yang sampai saat ini masih menjadi primadona di pasar internasional dan merupakan ikan hias kelompok mahal, serta fluktuasi di pasaranpun relatif stabil adalah ikan koi (Cyprinus carpio).

Ikan hias koi atau nishikigoi sebagai salah satu ikan hias yang banyak diminati karena keindahan bentuk badan serta warnanya, dan dipercaya membawa keuntungan oleh para pecinta koi di Indonesia. Jenis ikan koi yang memiliki harga cukup baik dan stabil di pasar dunia yaitu kohaku, taisho, sanshoku, showa, shiro, utsuri, shusui, asagi, goromo, goshiki, bekko, tancho, kinginrin, dan kawarimono (Anonim, 2010).

Potensi yang besar dari komoditas koi di Indonesia sebagai salah satu komoditas ikan hias unggulan yang cukup pesat belakangan ini, terutama pada beberapa daerah seperti Sukabumi, Cianjur, Jakarta Barat, Blitar, dan Makassar. Hal tersebut diduga karena budidaya koi di Jepang yang merupakan negara pembudidaya koi terbesar di dunia, mulai terkendala lahan sehingga peluang budidaya di Indonesia masih cukup besar untuk meraih potensi pasar yang terus meningkat. Besarnya nilai transaksi dan perdagangan koi di Indonesia membuat pemerintah melalui Kementerian Kelautan dan Perikanan (KKP) berminat membangun beberapa daerah sentra koi untuk menjadi daerah 
penghasil koi terbesar di tanah air melalui konsep minapolitan. Dengan adanya kegiatan tersebut, KKP mengembangkan potensi ikan hias nasional yang diharapkan dapat meningkatkan kualitas koi lokal yang dapat bersaing dengan koi impor baik di pasar domestik maupun internasional.

Komoditas ikan hias koi telah menjadi komoditas andalan di beberapa daerah seperti Sukabumi, Cianjur, dan Blitar karena telah berhasil mengangkat perekonomi masyarakat dan menjadikannya sebagai alternatif penghasilan selain padi. Para petani maupun pembudidaya koi di daerah tersebut terbentuk dalam kelompok-kelompok tani sehingga hasil produksi mereka tertata dengan baik meskipun cara budidaya yang dilakukan selama ini masih secara tradisional.

Guna mendukung produksi koi di beberapa sentra yang ada, penelitian untuk mengembangkan budidaya secara intensif yang dilakukan pada lingkungan terkontrol melalui perbaikan teknologi budidaya. Pengembangan budidaya yang dilakukan berlokasi di Balai Penelitian dan Pengembangan Budidaya Ikan Hias Depok, dengan pengambilan induk-induk dari beberapa sentra produksi koi baik Sukabumi, Cianjur, maupun Blitar. Pembenihan dilakukan secara alami, semi-buatan, dan murni buatan yang diharapkan benih yang dihasilkan akan mempunyai umur, ukuran yang seragam. Selain itu, kualitas telur yang dihasilkan juga lebih baik sehingga sintasan larvanya meningkat dibandingkan dengan pemijahan alami yang sering terkendala dengan pemeliharaan larva dengan sintasan yang rendah.

Penelitian pengembangan budidaya ikan hias koi yang dilakukan ini merupakan kegiatan sintesis informasi yang berarti pemaduan berbagai informasi dalam hal ini budidaya ikan koi, termasuk hasil penelitian yang akan diperoleh, sehingga diperoleh suatu kesimpulan yang selaras. Hal ini berarti kegiatan utama ialah pengumpulan informasi secara sistematis tentang budidaya ikan koi dan penarikan kesimpulan logis dari informasi tersebut. Tujuan dari penelitian ini yaitu mendapatkan data dan informasi tentang peningkatan produksi ikan hias koi melalui pengembangan budidayanya.

\section{BAHAN DAN METODE}

Penelitian pengembangan budidaya ikan hias koi di BPPBIH dilakukan mulai dari persiapan kolam pemeliharaan, pemijahan, inkubasi telur, pendederan, dan pembesaran, yang meliputi kolam beton berukuran $2 \mathrm{~m}$ x $6 \mathrm{~m}$ disekat dengan waring, kolam tanah berukuran $5 \mathrm{~m} \times 6 \mathrm{~m}$ untuk pembesaran, bak beton berukuran $2 \mathrm{~m} \times 2 \mathrm{~m}$ untuk pemijahan dan inkubasi telur dilakukan selama dua minggu. Kolam induk, pendederan, dan pembesaran dilengkapi dengan sirkulasi air deras (air tanah/pompa). Selanjutnya pengadaan induk-induk dari beberapa sentra produksi dan dibeli dari pembudidaya, serta dilakukan seleksi kualitasnya, kemudian pengangkutan induk dari daerah sentra produksi ke BPPBIH Depok dengan tansportasi darat untuk diadaptasikan di kolam terkontrol selama satu minggu.

Pemeliharaan induk di kolam beton berukuran secara terpisah antara induk jantan dan betina. Pakan yang diberikan berupa kombinasi pakan alami (cacing tanah) dan pakan komersial secara berseling sehari dua kali (pagi dan sore) secara ad libitum. Pelaksanaan pembenihan alami, semi-buatan, dan buatan murni dengan menggunakan induk 1:1, 1:2, dan 1:3, tergantung kesiapan induk yang ada. Pembuahan berlangsung semibuatan, sehingga setelah penyuntikan hormon, induk dipasangkan dalam kolam pemijahan dengan disertai shelter (kakaban). Larva yang menetas diinkubasi selama satu minggu di bak beton, selanjutnya ditebar di kolam pendederan selama satu bulan (sampling I), pakan yang diberikan berupa Tubifex sehari dua kali (ad libitum). Setelah larva berumur satu bulan dipindahkan ke kolam pembesaran (tanah) dengan pemberian pakan berupa pelet.

Sampling akan dilakukan satu bulan sekali untuk mengetahui pertumbuhnnya. Parameter yang diamati fekunditas, hatching rate, sintasan larva dan benih, pertambahan panjang dan bobot ikan, serta, dengan kualitas air sebagai pendukung. Perhitungan pertambahan biomassa dan laju pertambahan panjang bulanan menggunakan rumus sebagai berikut (Matricia et al., 1989):

$$
\mathrm{dW}=\mathrm{Wt}-\mathrm{W} 0
$$

$\mathrm{dW}=$ rataan pertumbuhan biomassa

$\mathrm{Wt}=$ biomassa rataan pada minggu kedelapan $(\mathrm{g})$

W0 = biomassa rataan pada awal penelitian $(\mathrm{g})$

$$
\mathrm{Gi}=[(\operatorname{Li}(\mathrm{t} 2)-\mathrm{Lo})] / 6
$$

$\mathrm{Gi}=$ perubahan panjang/bobot per bulan

Lo $=$ panjang/bobot awal percobaan

$\mathrm{Li}(\mathrm{t} 2)=$ panjang/bobot ikan ke-i pada minggu kedelapan

\section{HASIL DAN BAHASAN}

Persiapan kolam untuk budidaya meliputi perbaikan kolam tanah dan kolam beton, yang digunakan untuk adaptasi induk sampai pembesaran (Gambar 1). Pengolahan kolam meliputi kolam tanah untuk pendederan dan pembesaran serta kolam beton untuk pemijahan dan inkubasi telur.

Berdasarkan Gambar 1 terlihat bahwa pengolahan kolam tanah mulai dari pengeringan dan pengedukan ulang untuk perbaikan dasar kolam dan pematang. Kolam tanah yang diperbaiki sebanyak 20 kolam. Perbaikan kolam tanah dimulai dari pemupukan dengan kotoran ayam untuk menumbuhkan pakan alami yang nantinya berguna untuk pakan benih ikan koi yang ditebar. Pengairan kolam tanah tersebut 
dengan menggunakan air tanah (pompa). Sedangkan kolam beton berjumlah empat buah digunakan untuk pemijahan dan inkubasi telur.

Induk diperoleh dari beberapa pembudidaya di daerah Jawa Barat dan sekitarnya dan dari sentra produksi di Kabupaten Blitar. Jumlah induk yang digunakan untuk penelitian ini sebanyak 22 ekor rata-rata berukuran panjang 35-45 cm dan bobot 1,5-2,5 kg. Induk-induk tersebut terdiri atas beberapa strain yaitu showa, sanke, kohaku, dan bekko dengan perbandingan sembilan ekor jantan dan 13 ekor betina. Kondisi induk-induk tersebut hampir semua telah mencapai TKG II dan III (Gambar 2). Ukuran induk betina lebih besar dibandingkan dengan induk jantan. Demikian juga dengan umur masing-masing induk yang dikoleksi tersebut berkisar antara 1,5-2 tahun.

Kualitas induk lokal yang dikoleksi dari sentra produksi tersebut adalah grade B berdasarkan seleksi kecerahan warna, pola warna, penampilan tubuh, dan kebugaran. Kualitas induk dari keempat strain tersebut bervariasi, untuk strain showa pada grade yang sama memiliki kualitas yang terbaik dari semua aspek, disusul yang kedua adalah sanke, dan selanjutnya ogon. Untuk strain kohaku memiliki kualitas yang paling rendah dari ukuran dan warna.
Pemeliharaan induk pertama kali diadaptasikan di kolam beton BPPBIH selama dua minggu untuk mendapatkan kondisi yang stabil dan siap memijah. Pada pemeliharaan selama satu minggu tersebut indukinduk yang diadaptasikan terserang argulus untuk semua induk sebelum ditebar dan dipelihara di kolam tanah. Penanganan serangan argulus tersebut dengan perendaman PK dan garam untuk beberapa saat dan selanjutnya dipindahkan sementara ke kolam lain yang langsung terkena sinar matahari, serta dilakukan penggantian air. Untuk seterusnya induk-induk dipelihara pada kolam tanah berukuran $5 \mathrm{~m}$ x $6 \mathrm{~m}$.

Pakan yang diberikan untuk induk-induk adalah pelet komersial, dan untuk mempercepat kematangan gonad diseling dengan pakan alami yaitu cacing tanah. Pemberian pakan untuk induk dua kali sehari secara ad libitum. Komposisi pakan buatan (pelet komersial) dapat dilihat pada Tabel 1 .

Pemeliharaan induk dilakukan bertujuan untuk melakukan seleksi dan untuk mematangkan gonad agar ikan siap untuk dipijahkan dan diharapkan menghasilkan keturunan yang diinginkan. Induk dipelihara secara terpisah antara jantan dan betina untuk menghindari pemijahan massal.

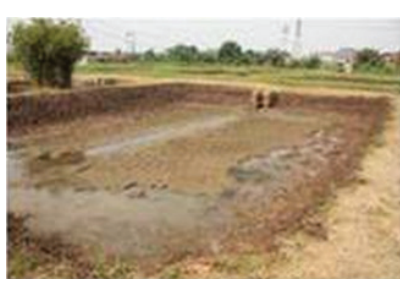

Gambar 1. Perbaikan kolam

Figure 1. Repair ponds
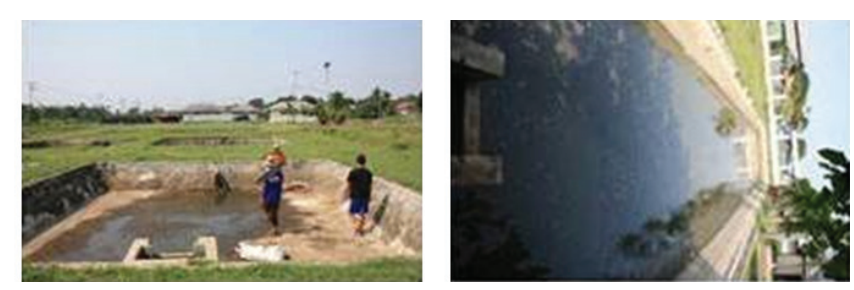

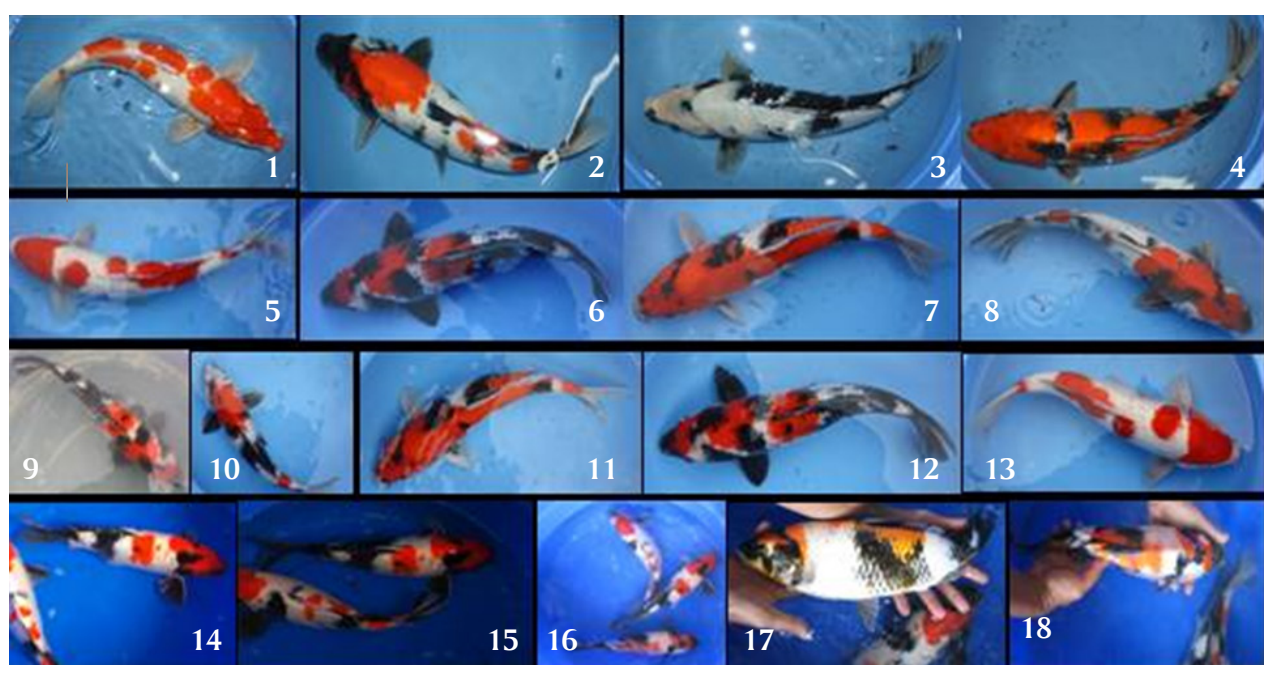

Gambar 2. Induk-induk ikan koi lokal yang dikoleksi dan digunakan untuk pembenihan $(1,5,13=$ Kohaku; 2, 4, 5, 6, 7, 8, 13, $14=$ showa; $3=$ bekko; 10, 11, $12=$ sanke)

Figure 2. Koi fish broodstocks collected and used for breeding (1, 5, $13=$ Kohaku; 2, 4, 5, 6, 7, 8, 13, 14 = showa; 3 = bekko; 10, 11, 12 = sanke) 
Tabel 1. Komposisi pakan buatan

Table 1. Composition of artificial feed

\begin{tabular}{lc}
\hline \multicolumn{1}{c}{ Parameter (Parameters) } & Persentase (Percentage) \\
\hline Protein kasar (Crude protein) & Minimal 35\% \\
Lemak kasar (Crude lipid) & Minimal 5\% \\
Serat kasar (Crude fibre) & Maksimal 3\% \\
Abu (Ash) & Maksimal 12\% \\
Kadar air (Water level) & Maksimal 12 \\
Kalsium (Calsium) & $2 \%$ \\
\hline
\end{tabular}

Tabel 2. Keragaan induk-induk ikan hias koi strain showa sebelum dipijahkan secara semi buatan

Table 2. Performance local fish koi showa strain showa before spawning in of artificial

\begin{tabular}{ccc}
\hline $\begin{array}{c}\text { Induk koi } \\
\text { Koi broodstock }\end{array}$ & $\begin{array}{c}\text { Panjang badan (PB) } \\
\text { Body length } \mathbf{( \mathbf { c m } )}\end{array}$ & $\begin{array}{c}\text { Bobot badan (BB) } \\
\text { Body weight }(\mathbf{g})\end{array}$ \\
\hline Betina I (Female I) & 39 & 1,008 \\
Betina II (Female II) & 38 & 880 \\
Jantan I (Male I) & 38 & 850 \\
Jantan I (Male I) & 37 & 840 \\
Jantan II (Male II) & 37 & 760 \\
Jantan II (Male II) & 35 & 650 \\
\hline
\end{tabular}

Setelah induk-induk dipelihara hampir tiga minggu di kolam tanah BPPBIH Depok, dilakukan seleksi induk yang matang gonad untuk dilakukan pemijahan. Pemijahan pertama dan kedua terdiri atas dua induk betina dan empat induk jantan dari strain showa. Sebelum dilakukan penyuntikan induk dikarantina selama satu hari, secara terpisah, dipuasakan, diukur panjang, dan ditimbang bobotnya (Tabel 2). Pemijahan dilakukan di kolam beton hatcheri berukuran $2 \mathrm{~m}$ x $2 \mathrm{~m}$ ketinggian air $1 \mathrm{~m}$ dengan perbandingan induk betina dan jantan 1:2. Sedangkan untuk performa induk-induk jantan dan betina yang siap untuk disuntik hormon tersebut dapat dilihat pada Gambar 3.

Pemijahan dilakukan dengan stimulasi hormon gonadotropin merk ovaprim@. Dosis hormon yang digunakan adalah $0,5 \mathrm{~mL} / \mathrm{kg}$ untuk induk betina dan $0,3 \mathrm{~mL} / \mathrm{kg}$ (Gambar 3). Penyuntikan keempat induk (Gambar 4) dilakukan pada sore hari pukul 16.17 untuk pemijahan I dan 16.30 untuk pemijahan II, dan selanjutnya dilepaskan pada bak pemijahan yang berukuran $2 \mathrm{~m}$ x $2 \mathrm{~m}$ yang disertai dengan kakaban yang berfungsi sebagai substrat untuk menempelnya telur-telur. Setiap bak diberi satu buah kakaban, yang sebelumnya dibesihkan dan dicuci untuk menjaga kontaminasi patogen. Setelah rentang waktu 9-10 jam pasca penyuntikan, terjadi ovulasi pada pukul 01.30 WIB, sedangkan pada induk-induknya dipindahkan ke media fiber setelah 4-5 jam setelah pembuahan, dan kakaban yang berisi telur diangkat dan dipindahkan ke bak inkubasi (Gambar 5).
Pengamatan hasil pemijahan meliputi fekunditas, ukuran telur, derajat penetasan, dan pertumbuhan. Penghitungan fekunditas dihitung berdasarkan pengukuran bobot induk sebelum dipijahkan dan setelah dipijahkan. Hasil pengukuran bobot induk betina setelah ovulasi ditampilkan pada Tabel 3 . Perkiraan fekunditas pada pemijahan pertama untuk dua induk betina lokal tersebut diperoleh \pm 7.500 telur dan 8.200 telur. Sedangkan untuk mengetahui bobot telur per butir diamati secara acak (di-sampling) dan ditimbang dengan timbangan o-house. Untuk bobot telur total yang dihasilkan pada pemijahan tersebut adalah sebesar sekitar $113 \mathrm{~g}$ dan $123 \mathrm{~g}$ dihitung dari bobot induk betina sebelum ovulasi dikurangi bobot induk betina setelah ovulasi, sedangkan bobot telur per butir sebesar 0,0015 g dilakukan pengukuran dengan tiga kali ulangan (Tabel 3). Fekunditas yang dihasilkan pada pemijahan ini relatif kecil, diduga disebabkan karena ikan masih dalam kondisi belum stabil karena baru diadaptasikan dari habitat asalnya ke lingkungan baru sehingga masih stres. Karena lingkungan yang baru sehingga napsu makan juga belum optimal. Di mana menurut Effendie (1997), bahwa fekunditas secara otomatis berhubungan dengan metabolisme yang mengadakan reaksi terhadap perubahan persediaan makanan dan menghasilkan perubahan dalam pertumbuhan telur yaitu ukuran dan umur telur, ukuran, dan jumlah telur, atau siklus pemijahan sendiri. Selain itu, ukuran induk yang relatif kecil dan belum pernah memijah dapat diduga juga sebagai penyebab 
Tabel 3. Keragaan induk-induk ikan hias koi setelah dipijahkan secara semi buatan

Table 3. Performance of koi fish broodstock after spawned with semiartificial

\begin{tabular}{lcc}
\hline $\begin{array}{c}\text { Induk koi } \\
\text { Koi broodstock }\end{array}$ & $\begin{array}{c}\text { Panjang badan }(\mathrm{PB}) \\
\text { Body length }(\mathbf{c m})\end{array}$ & $\begin{array}{c}\text { Bobot badan (BB) } \\
\text { Body weight }(\mathrm{g})\end{array}$ \\
\hline Betina I (Female I) & 39 & 895 \\
Betina II $($ Female II $)$ & 38 & 757 \\
\hline
\end{tabular}

Tabel 4. Keragaan fekunditas dan bobot telur pada pemijahan semi buatan Table 4. Performance of fecundity and weight of egg to semi-artificial spawning

\begin{tabular}{ccc}
\hline Jumlah telur (Total eggs) & Bobot telur (Weight of eggs ) & Rata-rata (Average ) (g) \\
\hline 10 & 0.0136 & 0.0014 \\
10 & 0.0148 & 0.0015 \\
10 & 0.0145 & 0.0015 \\
\hline
\end{tabular}

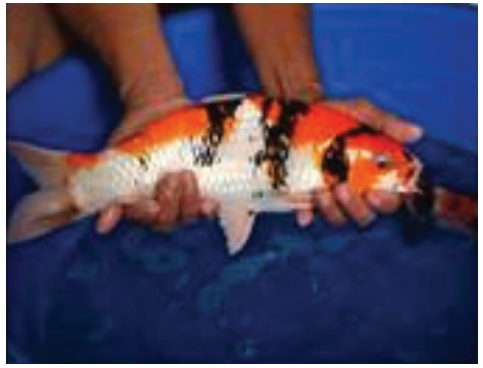

Pemijahan I

Spawning I

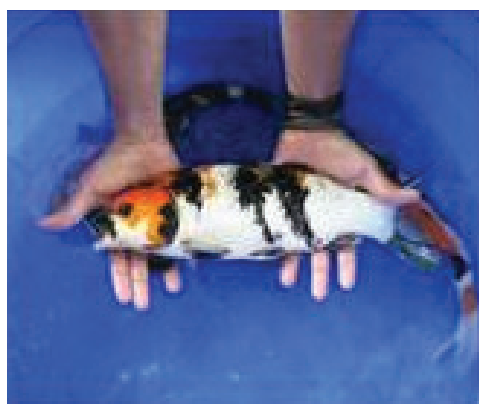

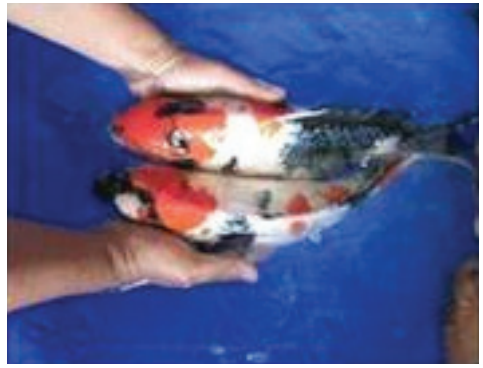

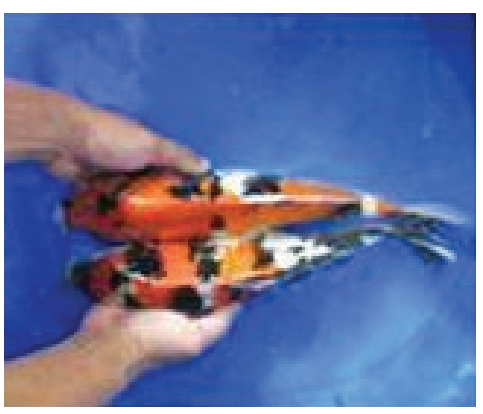

Gambar 3. Induk-induk ikan hias koi lokal yang digunakan untuk pemijahan I dan II strain showa $\mathrm{X}$ showa

Figure 3. Local fish broodstocks used for spawning I and II showa X showa strain

jumlah telur yang sedikit tersebut. Kemungkinan induk yang sama untuk pembenihan selanjutnya diharapkan menghasilkan telur yang jauh lebih tinggi, karena telah kondusif dan kebutuhan protein pakan lebih baik. Karena induk-induk tersebut telah adapted dengan lingkungan pemeliharaan yang baru, pakan yang sesuai dengan pertumbuhan dan perkembangan gonad, sehingga apabila dilakukan pembenihan diharapkan akan menghasilkan telur-telur yang berkualitas baik. Dengan demikian, sekalipun indukan lokal dapat menghasilkan iikan koi dengan grade yang lebih tinggi sehingga dapat bersaing di pasar domestik maupun internasional.
Parameter yang diamati setelah telur menetas adalah derajat penetasan (HR). Penghitungan HR tersebut dilakukan secara sampling dengan menggunakan saringan goyang masing-masing 100 butir dan dilakukan sebanyak tiga ulangan dan dilakukan setelah satu hari telur menetas. HR yang diperoleh adalah masing-masing sekitar 34,33\% dan 29,33\% dan proses penghitungan HR tersebut disajikan pada Gambar 6. HR yang diperoleh dari pemijahan ini juga termasuk kecil. Hal tersebut juga diduga akibat kondisi induk yang belum stabil, sehingga memengaruhi kualitas telur-telur yang dihasilkan, yang akhirnya penetasannya kurang maksimal, dan 

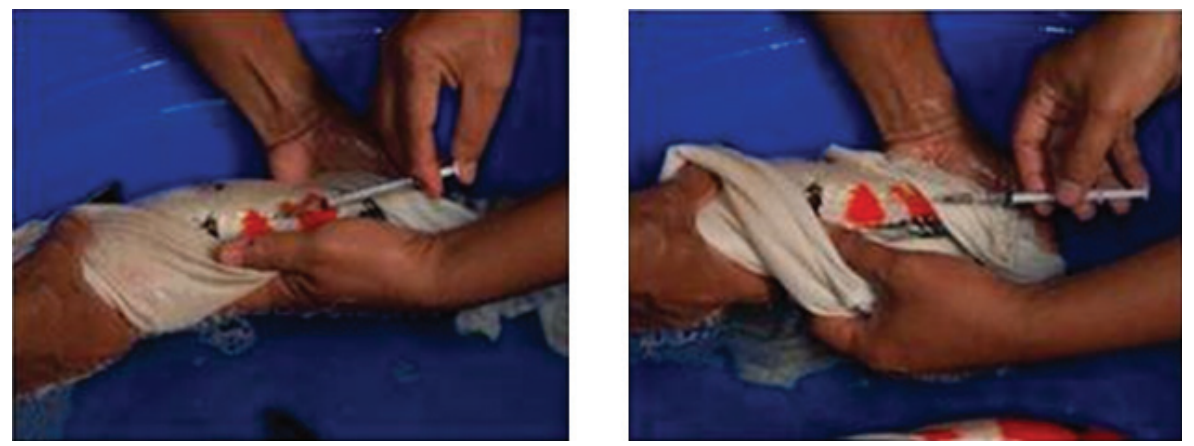

Gambar 4. Penyuntikan induk dengan hormon gonadotropin (kiri: pemijahan I dan kanan: pemjahan II)

Figure 4. Injecting with gonadotropin hormone (left: spawning I and right: spawning II)
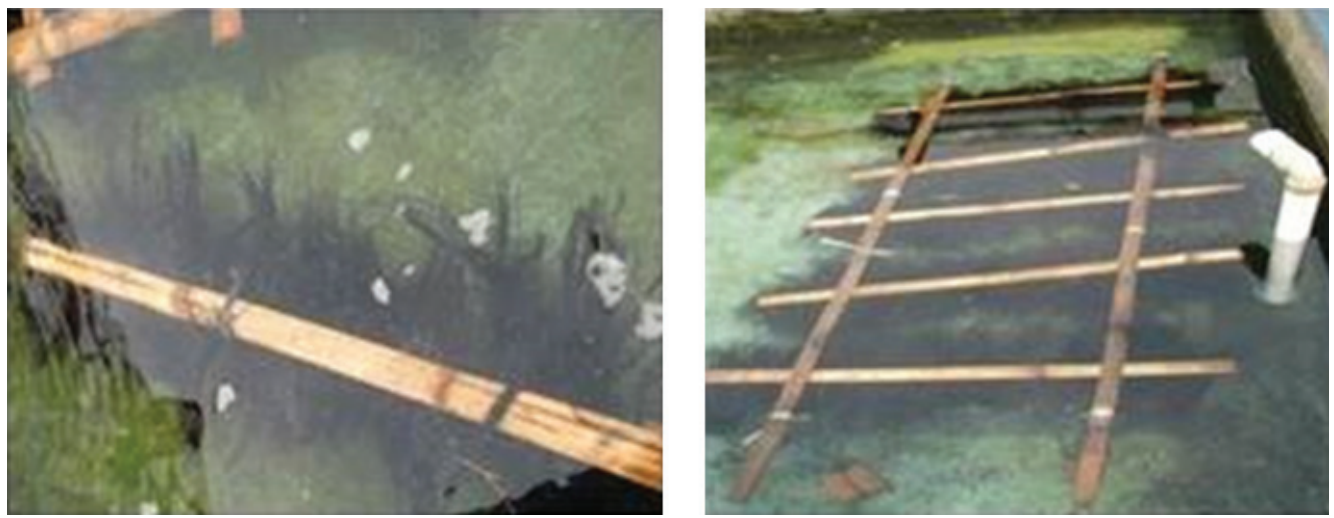

Gambar 5. Kakaban (substrat) pada bak pemijahan untuk menempelnya telur-telur (kiri: pemijahan I dan kanan: pemjahan II)

Figure 5. Substrat to spawning pond for attachment of eggs (left: spawning I and right: spawning II)
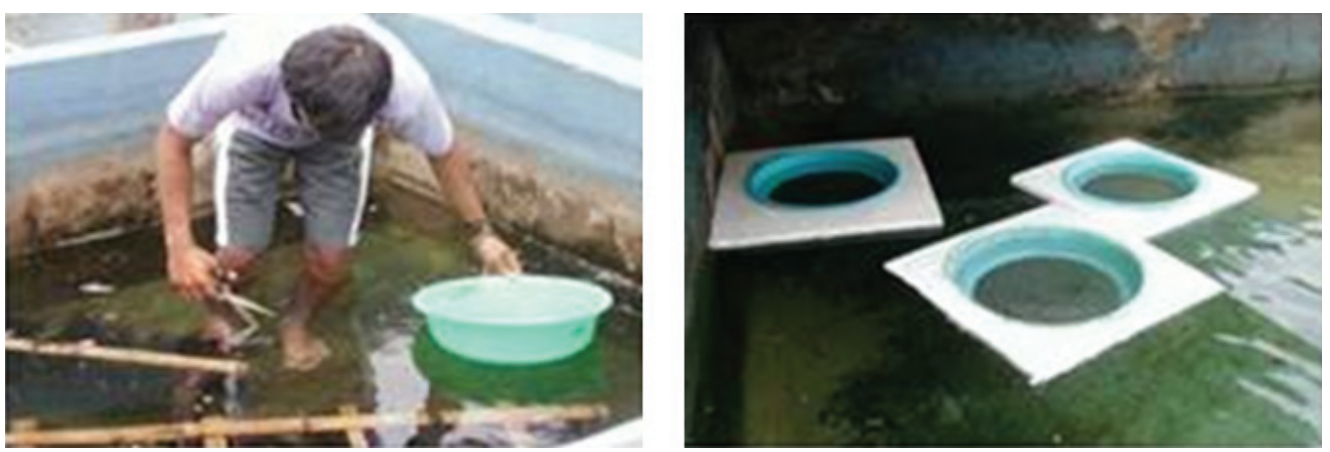

Gambar 6. Penghitungan derajat penetasan yang dilakukan secara sampling

Figure 6. Calculation of hatching rate conducted with sampling

banyak telur-telur yang fertil. Derajat penetasan yang optimal dalam kondisi lingkungan baik, indukan sehat dan baik dapat dihasilkan larva di atas 50\%. Daya tetas telur dipengaruhi oleh faktor makanan indukannya. Pada pemijahan I dan II dilakukan pada kondisi induk belum adapted secara optimal di lingkungan baru. Sama halnya dengan kondisi fekunditas yang masih rendah tersebut. Apalagi belum diketahui sebelumnya penetasan sebelumnya sebagai perbandingan karena induk tersebut baru pertama kali memijah dan baru berumur 1,5-2 tahun.
Larva pasca penetasan dipelihara tetap di dalam kolam beton (kolam pendederan) selama \pm 1 minggu. Pakan untuk larva tersebut selama masih mempunyai cadangan makanan kuning telur ditambahkan Artemia dan diseling dengan Moina sampai larva dipindah pada kolam pendederan. Pengamatan panjang larva dilakukan pada saat larva berumur satu hari dengan menggunakan mikroskop pembesaran $25 x$. Hasil yang didapatkan adalah panjang rata-rata $4,8 \mathrm{~mm}$ dan lebar badan $1,2 \mathrm{~mm}$. Performa larva tersebut dapat dilihat pada Gambar 7. 

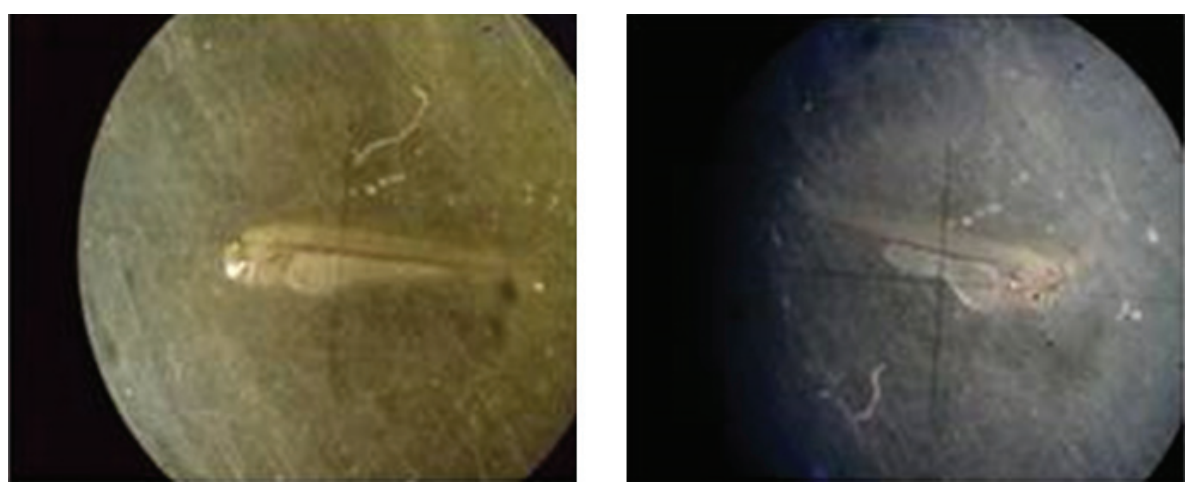

Gambar 7. Keragaan larva ikan koi pada pemijahan I dan II umur 1 hari

Figure 7. Performance of koi fish larvae at spawning I and II 1 day time

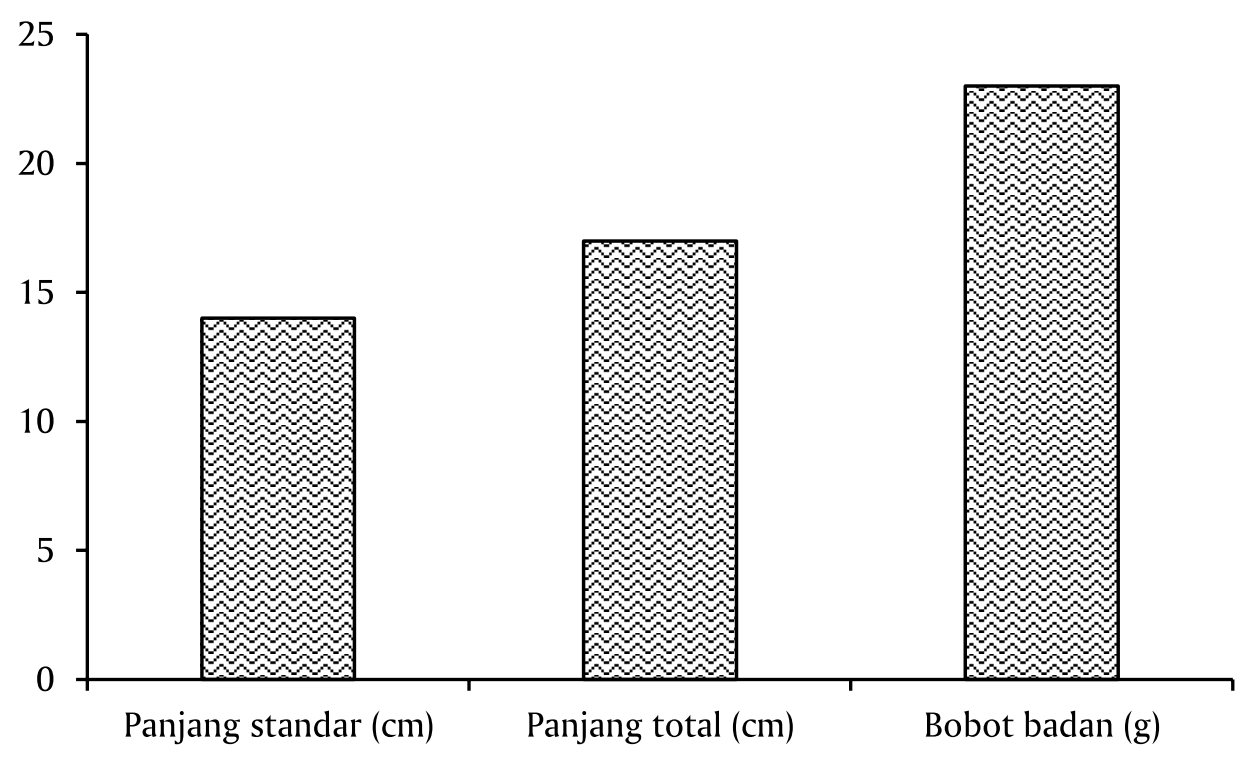

Gambar 8. Keragaan pertumbuhan benih pemijahan I

Figure 8. Performance of spawning I growth seed

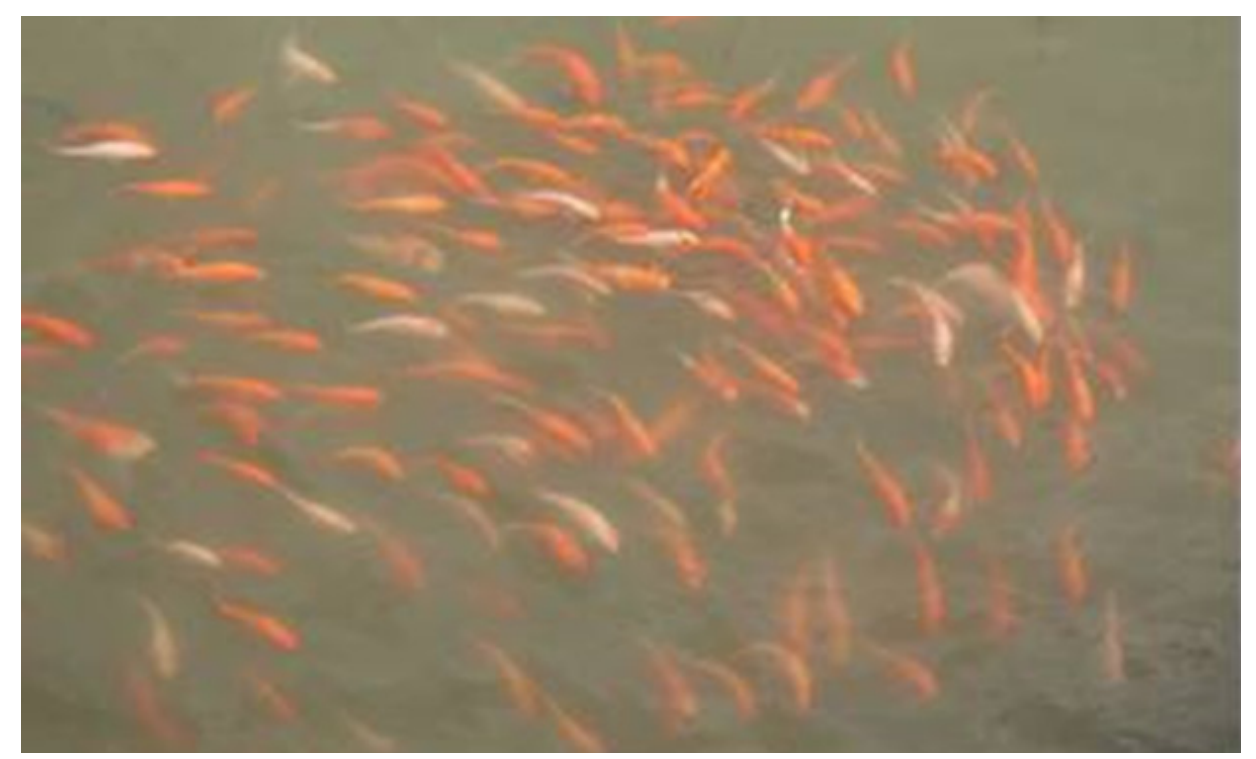

Gambar 9. Benih ikan hias koi hasil pemijahan I dan II strain showa X showa

Figure 9. Koi fish seed spawning I and II produced showa X showa strain 


\section{Pendederan}

Larva yang telah berumur satu minggu langsung ditebar pada kolam pendederan yang telah disiapkan. Pendederan dalam kolam bertujuan untuk membesarkan benih yang masih berukuran kecil. Pemindahan larva ke kolam pendederan dilakukan pada pagi hari atau sore hari untuk menghindari suhu yang terlalu tinggi yang dapat mematikan benih ikan. Sebelum benih ditebar, pastikan ketinggian air sudah mencapai $40 \mathrm{~cm}$ atau lebih agar fluktuasi suhu kisarannya tidak terlalu lebar. Pakan yang diberikan selain pakan alami yang telah tersedia pada kolam tanah tersebut, juga ditambahkan dengan cacing sutera. Hal ini dimaksudkan untuk mengantisipasi apabila pakan alami yang tersedia di kolam tidak mencukupi untuk kebutuhan larva, mengingat jumlah larva yang banyak.

\section{Pembesaran}

Pembesaran benih ikan hias koi dilakukan di kolam tanah yang lebih besar lagi sekaligus dilakukan penghitungan ulang untuk mengetahui sintasannya. Selain itu, dilakukan pengukuran panjang dan bobot secara acak untuk mengetahui petumbuhannya. Pakan yang diberikan adalah pelet komersial untuk benih (apung). Benih yang baru ditebar diberi sedikit pakan berupa pelet udang hingga umur kurang lebih 30 hari. Setelah itu, diberi pakan ikan koi (PK) komersial yang berbentuk pelet. Pakan pelet yang biasa digunakan memiliki kandungan protein kasar 35\%, lemak kasar 5\%, serat kasar $3 \%$, abu kasar $12 \%$, kadar air $12 \%$, dan kalsium $2 \%$. Kandungan protein yang tinggi dan penambahan kalsium pada pakan akan mempercepat pertumbuhan ikan. Pemberian pakan dilakukan sehari dua kali yaitu pada pagi hari dan sore hari. Metode pemberian pakan yaitu ad satiation (pemberian pakan sampai kenyang).

Pertumbuhan benih ikan hias koi diketahui dengan pengukuran panjang dan bobot yang dilakukan sebulan sekali secara acak sebanyak 50-100 ekor per kolam. Pada saat dilakukan sampling tersebut sekaligus dilakukan sortir kualitas benih menurut strain dan pola warna (pattern). Untuk benih yang tidak ada grade-nya disebut kropyokan dan biasanya dijual dengan harga per kilo seperti ikan konsumsi pada umumnya, namun harganya tetap lebih tinggi dibanding ikan konsumsi. Selanjutnya dilakukan penjarangan pemeliharaan agar pertumbuhannya lebih optimal dan grade ikan lebih cepat diketahui. Penjarangan bertujuan untuk memberi ruang gerak yang cukup bagi ikan koi. Seleksi bertujuan untuk mendapatkan ikan koi berkualitas baik. Keragaan pertumbuhan pemijahan I dan II rata-rata panjang dan bobot dapat dilihat pada Gambar 8, sedangkan keadaan populasi di kolam tanah dapat dilihat pada Gambar 9.

Kondisi benih pada saat ini telah berumur tiga bulan dengan jumlah individu sebanyak sekitar 1.200.000 dengan bobot rata-rata 23,545 g $\pm 2,576$ dan panjang total $16,855 \mathrm{~cm} \pm 0,693$. Anakan yang didapatkan adalah strain showa, kohaku, shiro, utsuri, dan kropyokan (pola warna yang tidak jelas). Persentase masing-masing belum dianalisis deskriptif secara pasti karena warna belum stabil. Sortir tetap dilakukan setiap bulan sampai bulan ke-7 untuk mendapatkan grade yang diharapkan.

\section{KESIMPULAN}

Hasil sementara pada penelitian pembenihan ikan hias koi (Cyprinus carpio) untuk beberapa strain dan metode pemijahan dapat diambil kesimpulan bahwa pemijahan semi buatan lebih efektif dilakukan karena dapat meningkatkan produksi terutama derajat penetasan yang lebih tinggi. Keberhasilan pembenihan juga sangat dipengaruhi oleh pengelolaan induk yang baik, manajemen pemberian pakan yang optimal, serta pengelolaan lingkungan yang lebih terkontrol, sehingga akan memengaruhi kebugaran induk, kematangan gonad, dan kualitas telur yang akhirnya dapat meningkatkan produksi benih secara keseluruhan.

\section{DAFTAR ACUAN}

Effendie, M.I. (1997). Metode biologi perikanan. Yayasan Dewi Sri. Bogor, $163 \mathrm{hlm}$.

Muhammad, F. (2010). Target ekspor ikan hias di Indonesia 2010. Bussines News Jakarta, 11 Mei 2010, 1 pp.

Muller, F., Williams, D.W., Konolak, J., Gauvry, L., Goldspink, G., Orban, L., \& Maclean, N. (1997). Activator effect of coinjected enhancers on the muscle-specific expression of promoter in zebrafish embryos. Mol. Rep. Dev., 47, 404-412.

Manikandavelu, D., Raveneswaran, K., \& Sivakumar, T. (2009). Breeding of koi carp (Cyprinus carpio) and gold fish (Carassius auratus) using Synchromate B. (GnRh regulator). Tamilnadu J. Veterinary \& Animal Sciences, 5(6), 225-227.

Twigg, D. (2008). Buku pintar koi. PT Gramedia. Jakarta, $133 \mathrm{hlm}$. 